\title{
Microclimatic and Environmental Surveillance of Operating Theaters: Trend and Future Perspectives
}

\author{
Margherita Ferrante ${ }^{1,2} \oplus$, Gea Oliveri Conti ${ }^{1, *} \mathbb{0}$, Giuseppe Lucio Blandini ${ }^{3}$, Giuseppe Cacia ${ }^{3}$, Carlo Distefano ${ }^{3}$, \\ Giulia Distefano $^{3}$, Valerio Mantione ${ }^{3}$, Agata Ursino ${ }^{1}$, Giuseppa Milletari ${ }^{2}$, Maria Anna Coniglio ${ }^{2}$ and \\ Maria Fiore ${ }^{1} \mathbb{D}$
}

check for updates

Citation: Ferrante, M.; Oliveri Conti, G.; Blandini, G.L.; Cacia, G.; Distefano, C.; Distefano, G.; Mantione, V.; Ursino, A.; Milletari, G.; Coniglio, M.A.; et al. Microclimatic and Environmental Surveillance of Operating Theaters: Trend and Future Perspectives. Atmosphere 2021, 12, 1273. https://doi.org/10.3390/ atmos12101273

Academic Editor: Rafael Borge

Received: 31 July 2021

Accepted: 22 September 2021

Published: 30 September 2021

Publisher's Note: MDPI stays neutral with regard to jurisdictional claims in published maps and institutional affiliations.

Copyright: (c) 2021 by the authors. Licensee MDPI, Basel, Switzerland. This article is an open access article distributed under the terms and conditions of the Creative Commons Attribution (CC BY) license (https:/ / creativecommons.org/licenses/by/ $4.0 /)$.
1 Environmental and Food Hygiene Laboratory (LIAA), Department of Medical, Surgical Sciences and Advanced Technologies “G.F. Ingrassia" of University of Catania, Via Santa Sofia 87, 95123 Catania, Italy; marfer@unict.it (M.F.); aursino@unict.it (A.U.); mfiore@unict.it (M.F.)

2 Hygiene Complex Operative Unit, University Hospital “G. Rodolico-San Marco", Via Santa Sofia 78, 95123 Catania, Italy; milletari@policlinico.unict.it (G.M.); ma.coniglio@unict.it (M.A.C.)

3 Medical Specialization School in Hygiene and Preventive Medicine, Department of Medical, Surgical Sciences and Advanced Technologies "G.F. Ingrassia" of University of Catania, Via Santa Sofia 87, 95123 Catania, Italy; giublalu@gmail.com (G.L.B.); peppecacia@live.it (G.C.); carlodistef@gmail.com (C.D.); distefano-giulia@virgilio.it (G.D.); valerio.mantione@gmail.com (V.M.)

* Correspondence: olivericonti@unict.it

\begin{abstract}
The health risk level in operating rooms is correlated to the safety levels of microclimatic parameters, thermal indices, anesthetic gases and microbiological parameters. The objective of this study was to estimate the staff and medical service management compliance with the suggestions resulting from monitoring. Methods: The environmental conditions of 38 different operating rooms in the Sicily region, Italy, from January 2011 to December 2020 were monitored. The results were compared with specific standards suggested by national and international laws and guidelines. Results: Almost all microclimatic and microbiological parameters were outside the limits. The monitoring of the anesthetic gases showed that $5.6 \%$ of sevoflurane measurements exceeded the limit values. Conclusions: Constant environmental monitoring is an essential element for maintaining optimal living conditions in the working environment. The compliance of staff with guidelines and rules is a fundamental parameter for achieving this objective.
\end{abstract}

Keywords: operating rooms; microclimatic monitoring; Sicily region; guidelines

\section{Introduction}

The volume of surgical procedures is increasing around the world with a daily average of 235 million interventions. Hence, a data analysis of operating theaters is crucial for hospital managers to minimize risks [1]. In particular, a performance evaluation of efficiency, effectiveness and safety are the basis for surgical risk management.

The environmental quality of operating rooms is pivotal to ensure the health of both workers and patients as well as the productivity of workers [2]. Therefore, optimal microclimatic and microbiological conditions should be identified and maintained to guarantee a healthy, safe and comfortable environment. Temperature, humidity, lighting and ventilation-referred to as microclimatic parameters-may affect the wellness of workers and patients [3].

Environmental microbiological controls in operating theatres are of great importance in preventing surgical-site infections. Microbiological risk is influenced by many factors such as the air system, maintenance, cleaning and disinfection process [4,5].

Microbiological monitoring of the microclimate and careful cleaning of the surfaces are very important: a poor quality of these parameters determines a negative impact on the health of patients in terms of the average post-operative hospitalization time as well as the occurrence and duration of fever $\left(>37.5^{\circ} \mathrm{C}\right)$ and microbiological contamination of 
surgical wounds [6-8]. The critical areas are horizontal surfaces because these are the most exposed to settling/contamination [9]. Compliance with optimal environmental standards and hand hygiene prevent post-operative infections. Infections from the surgical-site affect thousands of patients, increasing public spending and post-operative hospitalization times [10].

It is important to monitor the levels of anesthetic gases in operating rooms, both for the consequences on operators and for the consequences on the environment, through appropriate disposal systems and constant monitoring [11]. A continuous exposure to anesthetic gases can cause damage to the health of exposed people. Their health impact is shown by neurotoxic, immunosuppressive, hepatotoxic and reproductive effects [12]. The national authority has promulgated several guidelines [13-18] about the monitoring of microclimatic conditions in operating rooms to prevent injuries and diseases and to improve working conditions. These are well-structured guidelines, which, if followed closely, lead to effective and efficient results. However, the guidelines resulting from their application is not perceived as mandatory and necessary. This may lead to the underestimation of their importance, showing that stricter regulations are probably needed.

Moreover, the health risk grade in operating theatres is directly related to the security level offered by the health facilities; for this reason, the adjustment to the national regulatory plan on health and safety at work is compulsory, with careful attention paid to the health area. In particular, the risk in operating theatres is closely linked to safety levels, ventilation systems, operator comfort, operating equipment, personal protective equipment and the training of healthcare workers $[19,20]$.

This study aims to estimate the compliance of staff and medical service management with the indications deriving from monitoring actions.

\section{Materials and Methods}

We analyzed the environmental conditions of 38 different operating rooms weekly in the Sicily region, Italy, from January 2011 to December 2020. The monitoring included the microclimatic parameters (air temperature, relative humidity, air velocity), air changes/hour, thermal indices (PMV, PPD), anesthetic gases (nitrous oxide, sevoflurane) and microbiologic parameters (mycetes, microbial load at $22^{\circ} \mathrm{C}$ and $37^{\circ} \mathrm{C}$ ).

For the microclimatic parameters (air temperature, relative humidity, air velocity), an LSI laser microclimate control unit and a data logger (M-Log) [21] were used according to the standard ISO 7730 [22] in an "at rest" (state before the use) and "in operation" (during the surgical activity) operating room.

The microbiological monitoring (mycetes, microbial load of $22^{\circ} \mathrm{C}$ and $37^{\circ} \mathrm{C}$ ) on the operating rooms was performed both for air and surface quality checks. The air sampling was carried out using a Surface Air System (SAS) [23] both for at rest and in operation conditions according to the standard ISPESL guideline for operating room security [15]. The examined surfaces included the operating plans, scialytic lamps, operating carts and walls. The method used employed Plate Count Agar (PCA), a non-selective culture medium composed of agar, tryptone, yeast extract and dextrose with a $\mathrm{pH}$ of 7 . The plates were incubated for $72 \mathrm{~h}$ at a temperature of $22{ }^{\circ} \mathrm{C}$. The plates used for counting the total microbial load were incubated for $48 \mathrm{~h}$ at $37^{\circ} \mathrm{C}$. The presence of yeasts and molds was evaluated using Sabouraud Dextrose Agar (dextrose $40 \mathrm{~g} / \mathrm{L}$, peptone $10 \mathrm{~g} / \mathrm{L}$, agar $15 \mathrm{~g} / \mathrm{L}$ added to chloramphenicol; the $\mathrm{pH}$ was $5.6 \pm 0.2$ at a temperature of $25^{\circ} \mathrm{C}$ ) after an incubation at $22{ }^{\circ} \mathrm{C}$ for 5 days.

The results of the surface samples were expressed in $\mathrm{CFU} / \mathrm{cm}^{2}$ (average colonyforming units or CFUs per square centimeter) whereas the results of the air samples were expressed in $\mathrm{CFU} / \mathrm{m}^{3}$. The sterilization procedures were carried out according to ISO EN 14937 regulatory laws [24-27].

Regarding the evaluation of the microclimatic parameters, the subjective feeling of wellbeing does not depend on only one of the related environmental factors (temperature, humidity, air speed, etc.) but on their combination and interactions. We therefore used the 
Fanger approach according to the ISPESL guideline for operating room security and ISO $7730[15,22]$.

The statistical analysis was performed using statistical software SPSS for Windows (Statistical Package for the Social Sciences, version 21.0; SPSS Inc., Chicago, IL, USA). Out of limit values and range out of limit values were expressed as absolute frequencies (\%) and min-max, respectively. Both out of limit values and range out of limit values were stratified by operating theatre status (in operation and at rest). Boxplots and line graphs were used to describe the continuous variables and the annual trend of unfitting values, respectively.

\section{Results}

A total of 38 operating theatres (OTs) were monitored from January 2011 to December 2020.

Table 1 shows the number, type and results of the environmental controls in 38 operating theatres of several public hospitals in Sicily, Italy.

Table 1. Number, type and results of the environmental controls in the period 2011-2020 in the operational theatres of the Sicily region, Italy.

\begin{tabular}{|c|c|c|c|}
\hline Type of Control & $\begin{array}{c}\text { Total Controls } \\
\text { n. }\end{array}$ & $\begin{array}{l}\text { Out of Limits } \\
\text { n. }(\%)\end{array}$ & $\begin{array}{c}\text { Range Out of Limits } \\
\text { (Min-Max) }\end{array}$ \\
\hline Microclimatic Monitoring & 434 & $420(96.8)$ & \\
\hline & 434 & $66(19.6)$ & $24.5-27.1(\mathrm{a})$ \\
\hline Air Temperature $\left({ }^{\circ} \mathrm{C}\right)$ & & & $15.0-19.0(\mathrm{~b})$ \\
\hline & 434 & $221(50.9)$ & $60.8-87.9$ (a) \\
\hline Relative Humidity (\%) & & & $17.5-39.6(b)$ \\
\hline & 434 & $401(92.4)$ & $0.20-0.25$ (a) \\
\hline Air Velocity (m/s) & & & $0.00-0.04(b)$ \\
\hline$P M V$ & 225 & $48(20.5)$ & $-2.89-1.03$ \\
\hline $\begin{array}{r}\text { Health Professionals } \\
\text { Patients }\end{array}$ & 196 & $186(79.5)$ & $-3.80-3.76$ \\
\hline$P P D$ & 225 & $50(21.2)$ & $10.06-98.54$ \\
\hline $\begin{array}{r}\text { Health Professionals } \\
\text { Patients }\end{array}$ & 196 & $186(78.8)$ & $10.06-100$ \\
\hline $\begin{array}{l}\text { Air Changes/Hour } \\
\text { Anesthetic Gases }\end{array}$ & 398 & $125(31.4) * *$ & $0-14.0$ \\
\hline Nitrous Oxide (ppm) & 233 & n.a. & n.a. \\
\hline Sevoflurane (ppm) & 233 & $13(5.6) * *$ & $2.3-15.3$ \\
\hline
\end{tabular}

Limits adopted: air temperature $\left(20-24{ }^{\circ} \mathrm{C}\right)$; relative humidity (40-60\%); air velocity $(0.05-0.15 \mathrm{~m} / \mathrm{s}) ;$ PMV $( \pm 0.5)$ PPD ( $\leq 10 \%)$; (a) unfit for exceeding the upper limit; (b) unfit for exceeding the lower limit. ${ }^{* *}$ Limits adopted: $\geq 15$ air changes/hour; ** limits adopted: TLV-TWA of $50 \mathrm{ppm}$ for nitrous oxide and a TLV ceiling of $2 \mathrm{ppm}$ for halogen. n.a. (not applicable).

The microclimatic parameters $(n=434)$ and from the air changes/hour (398) were the most frequently controlled parameters, among which we found that almost $1 / 4$ were out of limits (Table 1; Figure 1). We found values out of limits for upper and lower air temperature limits (upper limit $24^{\circ} \mathrm{C}$ vs. $24.84^{\circ} \mathrm{C}$; lower air temperature limit $20^{\circ} \mathrm{C}$ vs. $\left.19.2^{\circ} \mathrm{C}\right)$.

Relative humidity (RH) values, as shown in Table 1, had a percentage of unsuitability for about half of the samples examined. The unsuitable relative humidity median values found in operating theatres for exceeding the upper and lower limits $(60 \%$ and $40 \%)$ were $67.3^{\circ} \mathrm{C}$. Overall, the air velocity (AV) samples examined were unsuitable and the median value exceeding the lower air speed limit $(0.05 \mathrm{~m} / \mathrm{s})$ was $0.00 \mathrm{~m} / \mathrm{s}$.

The thermal comfort indices (PMV and PPD) had a non-compliance for about $4 / 5$ of the total for patients and about $1 / 5$ for healthcare workers (Table 1, Figure 1).

Moreover, about 1/3 (125/398) of the total examined air changes/hour did not conform to the reference values (Table 1; Figure 1); in particular, the unsuitable OTs had a number of air-median changes of 9.8 .

The percentage trend of the microclimatic parameters, the indices of thermal comfort and the air changes/hour unfitting values are shown in Figure 2. The slight improvement 
trend could be due both to the reduced controls linked to the pandemic restrictions as well as to the technical interventions carried out over the years.
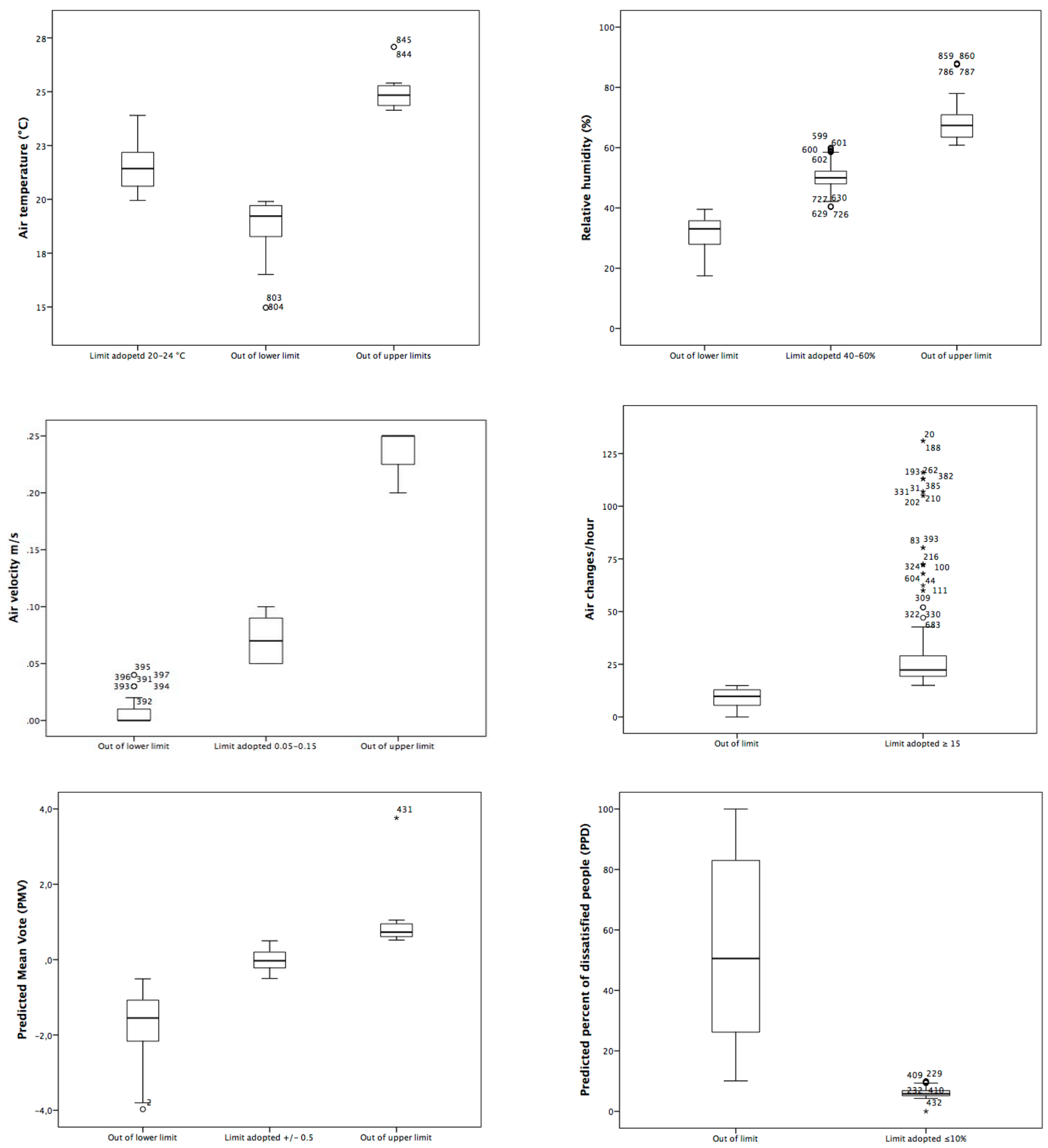

Figure 1. Distribution of the microclimatic parameters (air temperature, relative humidity, and air velocity); air changes/hour and indices of thermal comfort (PMV and PPD) by fitting and unfitting limit values. "**": extreme outline value. “०”: mid outline value. 


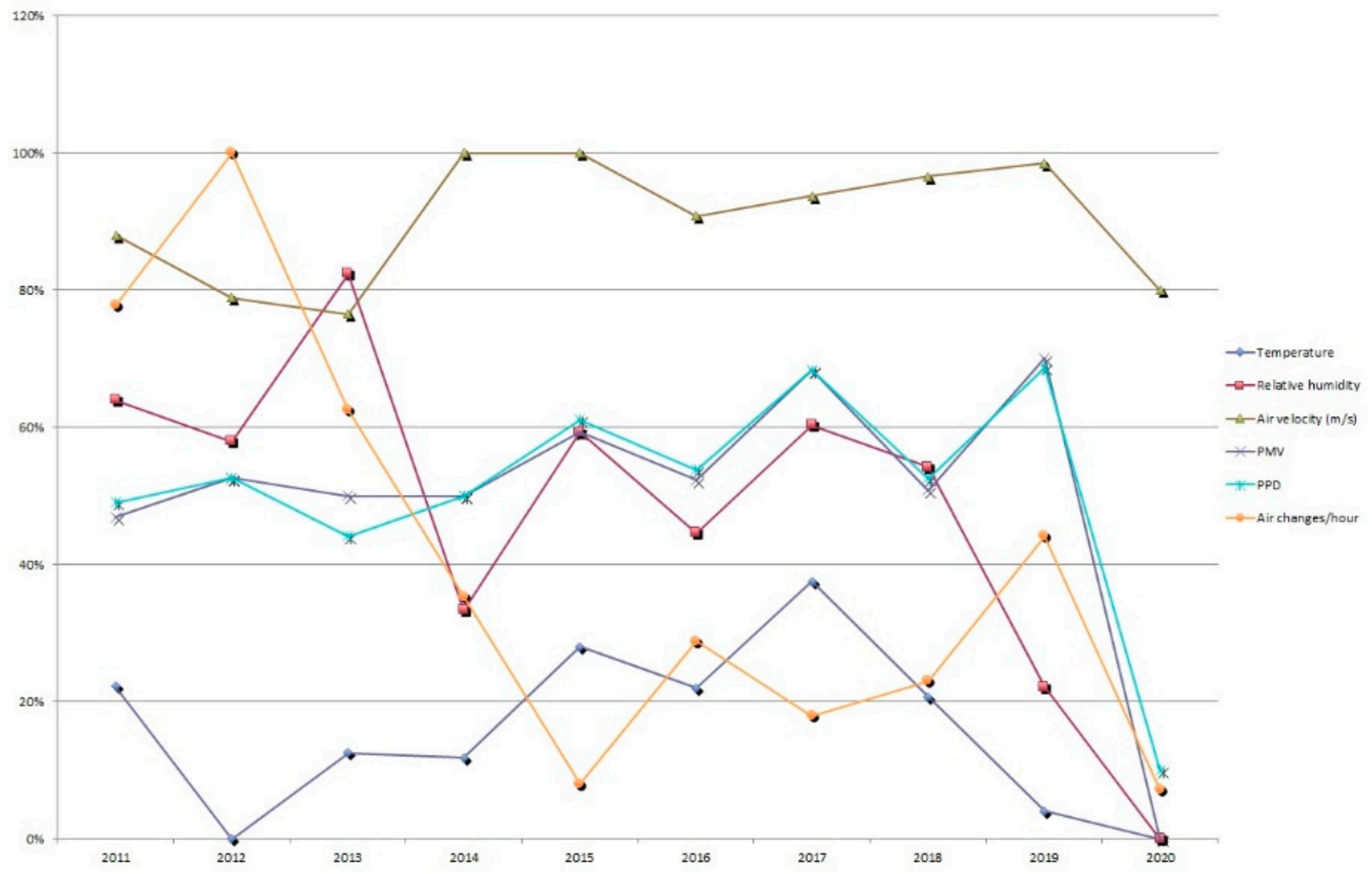

Figure 2. Trend of unfitting values of the microclimatic parameters, indices of thermal comfort (PMV and PPD) and air changes/hour.

A total of 466 controls of anesthetic gas $\left(\mathrm{N}_{2} \mathrm{O}\right.$ and sevoflurane) were carried out (Table 1). An analysis of the data showed that for the detections of $\mathrm{N}_{2} \mathrm{O}$, it was not possible to assess a non-conformity situation in reference to the TLV-TWA $50 \mathrm{ppm}$ taken as the limit for OT constructed and/or refurbished after 1989. We observed non-conformity for sevoflurane monitoring in $5.6 \%(\mathrm{~N}=13)$ of samples compared with the TLV ceiling $(2 \mathrm{ppm})$ [14]. The average concentration was $7.60 \pm 1.9 \mathrm{ppm}$ (range out of limit: 2.3-15.3) [28,29].

A small proportion of air microbial load monitoring at $22{ }^{\circ} \mathrm{C}$ and $37^{\circ} \mathrm{C}$, both in operation and at rest sampling, exceeded the limit values whereas about $1 / 3$ of the samples concerning mycetes exceeded the limit value both in operation and at rest states (Table 2). The distribution of mycetes by the state of the operating theatres and the distribution of the microbial load at $22{ }^{\circ} \mathrm{C}$ and $37^{\circ} \mathrm{C}$ in air showed that about $1 / 10\left(31 / 315\right.$ at $22{ }^{\circ} \mathrm{C}$ and $34 / 315$ at $37^{\circ} \mathrm{C}$ ) of the total data examined did not conform to the reference values (Figure 3).

Table 2 also shows the results of the microbiological sampling on the operating theatre surfaces (operating table, surgical lamp and operating instrument table). On the surgical lamp, 461 samples were taken at $22^{\circ} \mathrm{C}$ and another 464 at a temperature of $37^{\circ} \mathrm{C}$, of which 284 were taken in the operating room; 177 samples at $22{ }^{\circ} \mathrm{C}$ and 180 at $37^{\circ} \mathrm{C}$ in empty rooms were also collected.

The results showed that a small percentage of the microbiological samples at $22{ }^{\circ} \mathrm{C}$ exceeded the minimum and maximum limits adopted for the operating theatre both in operation and at rest; the same applied to the microbiological samples at $37^{\circ} \mathrm{C}$, which showed values out of range.

Finally, 35 and 155 samples taken from the surgical instrument table in operation and at rest, respectively, for microbial load at $37^{\circ} \mathrm{C}$ exceeded the reference limits (Table 2). 
Table 2. Number, type and results of the microbiological controls of operating theaters in the period 2011-2020.

\begin{tabular}{|c|c|c|c|c|c|c|}
\hline \multirow[t]{2}{*}{ Type of Control } & \multicolumn{2}{|c|}{$\begin{array}{c}\text { Total Control } \\
\text { N }\end{array}$} & \multicolumn{2}{|c|}{$\begin{array}{c}\text { Out of Limits } \\
\text { N (\%) }\end{array}$} & \multicolumn{2}{|c|}{$\begin{array}{l}\text { Range Out of Limits } \\
\text { (Min-Max) }\end{array}$} \\
\hline & In Operation & At Rest & In Operation & At Rest & In Operation & At Rest \\
\hline Microbial Load $22^{\circ} \mathrm{C}$ & & & & & & \\
\hline $\begin{array}{l}\text { Air }\left(<35 \mathrm{Ufc} / \mathrm{cm}^{3}\right) \\
\text { Surfaces }\left(<0.5 \mathrm{Ufc} / \mathrm{cm}^{2}\right)\end{array}$ & 315 & 190 & $31(9.7)$ & $12(6.1)$ & $40-510$ & $40-550$ \\
\hline Operating Table & 7 & 4 & $4(57.1)$ & $1(25.0)$ & $1-2$ & n.a. \\
\hline Surgical Light & 284 & 177 & $36(12.9)$ & $32(18.1)$ & $1-22$ & $1-16$ \\
\hline $\begin{array}{l}\text { Surgical Instrument Table } \\
\text { Microbial Load } 37^{\circ} \mathrm{C}\end{array}$ & 35 & 155 & $9(25.7)$ & $27(17.5)$ & $1-2$ & $1-42$ \\
\hline $\begin{array}{l}\text { Air }\left(<35 \mathrm{Ufc} / \mathrm{cm}^{3}\right) \\
\text { Surfaces }\left(<0.5 \mathrm{Ufc} / \mathrm{cm}^{2}\right)\end{array}$ & 315 & 190 & $34(10.6)$ & $15(7.8)$ & $40-500$ & $40-514$ \\
\hline Operating Table & 7 & 4 & $3(42.9)$ & 0 & $1-2$ & n.a. \\
\hline Surgical Light & 284 & 180 & $38(13.4)$ & $40(22.2)$ & $1-21$ & $1-40$ \\
\hline $\begin{array}{l}\text { Surgical Instrument Table } \\
\text { Micetes (Absent) }\end{array}$ & 35 & 155 & $7(20)$ & $42(27.1)$ & $1-2$ & $1-33$ \\
\hline $\begin{array}{l}\text { Air }\left(<35 \mathrm{Ufc} / \mathrm{cm}^{3}\right) \\
\text { Surfaces }\left(<0.5 \mathrm{Ufc} / \mathrm{cm}^{2}\right)\end{array}$ & 315 & 190 & $98(31.1)$ & $53(27.3)$ & $1-250$ & $1-110$ \\
\hline Operating Table & 7 & 4 & 0 & 0 & 0 & 0 \\
\hline Surgical Light & 286 & 179 & $8(2.8)$ & $15(8.4)$ & $1-10$ & $1-10$ \\
\hline Surgical Instrument Table & 35 & 155 & $2(5.7)$ & $11(7.1)$ & $1-1$ & $1-10$ \\
\hline
\end{tabular}

n.a.: not applicable because of zero frequencies.
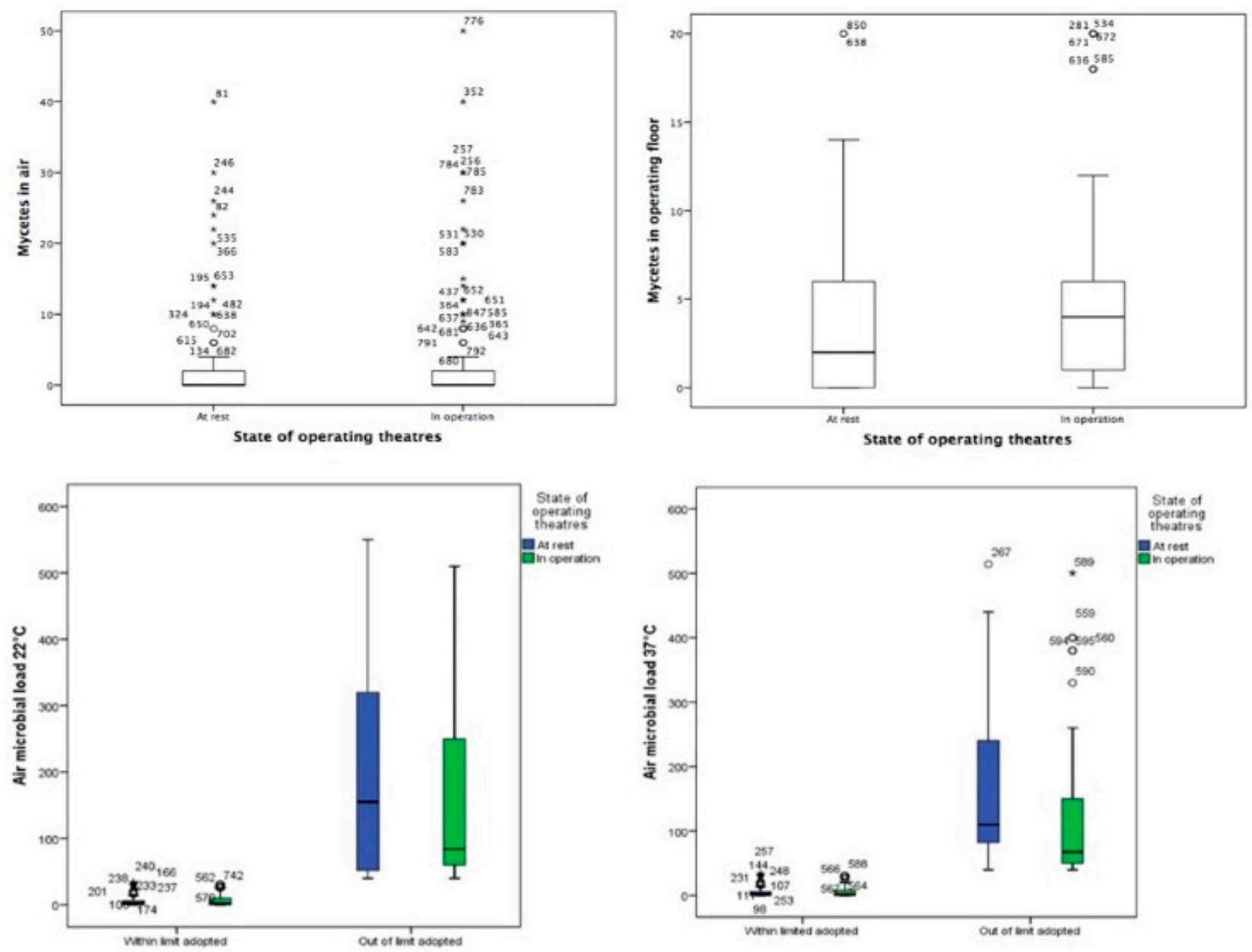

Figure 3. Distribution of the microbial load of mycetes at $22^{\circ} \mathrm{C}$ and $37^{\circ} \mathrm{C}$ in air by fitting and unfitting limit values. "**: extreme outline value. "o": mid outline value. 


\section{Discussion}

This study shows the importance of correct procedures to be carried out in operating theatres to maintain high safety standards; it is important and necessary to instruct the personnel employed in the expected practices (accurate washing of hands, sanitizing of environments, proper use of DPI) and strict compliance with these procedures. Both the compliance and continuous training of the entire staff are necessary to reduce microbiological risk and for the correct maintenance.

This study showed that almost all of the microclimatic results obtained from the 434 examinations performed on the 38 operating rooms were over the limits. In particular, the air speed was the most frequently altered parameter among all the examined microclimate parameters. Air flow patterns in the operating theatre are a key parameter in the microclimatic control of operating rooms [30]. However, this parameter does not significantly affect the need for air changes; in fact, a low percentage $(31.4 \%)$ was shown out of the normal range.

Nevertheless, it is important not to underestimate the values of air speed, as reported by Tang and Wan's study performed in Taiwan. The authors reported that the quality of the environmental air strongly affected the life and yield of the health workers as well as the patients [31]. A key element of management is the correct functioning and modernization of air ventilation systems and their periodic maintenance (change of filters, modernization of the structures, etc.) [32].

The results of the analysis of the anesthetic gases, particularly concerning nitrous oxide, showed that the values complied with the reference limits found in the literature. The sevoflurane results showed that $5.6 \%$ of the measurements were over the limits. This aspect should be better investigated through a further analysis on the exposed subjects in order to detect the metabolites in urine $[29,33]$.

In the overall rating of microclimatic welfare (PMV and PPD) with reference to the operators and to the patients inside the examined operating rooms, a significant difference in the percentage of comfort to the detriment of the patients was found. Although a tolerance of $20 \%$ in the data of the operator was permitted, a remarkable discomfort concerning the thermo-hygrometric wellbeing of the patient was found of 79.5\% for the PMV and $78.8 \%$ for the PPD; this gap should be minimized, as also pointed out by the literature [19].

Regarding the results of the microbiological analysis concerning the operating rooms, it was shown that the microbic growth at $22{ }^{\circ} \mathrm{C}$ (air temperature) was out of the reference range in $9.7 \%$ of the cases of in operation measurements whereas it was out of the limits in $6.1 \%$ of the cases with the at rest conditions. At $37^{\circ} \mathrm{C}$, there was a slight increase of the percentages both for in operation $(10.6 \%)$ and at rest $(7.8 \%)$.

It was apparent that, during surgical procedures in the operating theatres, the bacterial contamination was over the limit in all the considered parameters with higher percentages than in the at rest state. Despite this, the values were included in the range of acceptability.

The analysis of surfaces showed that the microbic growth at $22{ }^{\circ} \mathrm{C}$ was over the range for the lamp and the operating cart, both for in operation and at rest.

The mycetes on surfaces showed a worsening trend; in fact, fungi were found both in the air and on surfaces out of the limits. Specifically, the mycetes exceeded one third of the samples both at rest (31.1\%) and in operation (27.3\%). The results of the lamp and cart were similar or slightly lower.

One of the reasons that could influence and justify the criticalities that emerged from the results could be the insufficient compliance of the operators with regard to the respecting of the guidelines. Between the other necessary goal-interventions (upgraded internal guidelines, periodic maintenance of the cyber-physical systems (CPS), remote multi-parameter control), it is also very important to increase the knowledge and compliance of the operators.

CPS represent a good tool for the future management of monitoring decision-making and analysis. Recent advances in technology have empowered the widespread application of CPS in Industry 4.0. In this innovative context, Healthy Environment Monitoring 4.0 
can be proposed based on an integrated view of the intranet of hospital data and artificial intelligence (AI) technology [34]. The implementation of this new concept of technological monitoring will need a unified architecture to support the integration of different enabling technologies for operators but may be the best way to correct the management of hospital operational rooms.

A limit of this study could be the failure to administer a questionnaire to operators to investigate and assess their actual compliance. Measures would be useful in this respect.

\section{Conclusions}

This study showed the importance of constant environmental monitoring in operating rooms, however, the results showed also the poor staff and Medical Service Management compliance with the indications resulting from monitoring. The monitoring, in fact, appeared to be the pivotal instrument in reducing the whole environmental microbial load through the evaluation of parameters such as the salubrity of the air ventilation system and correct sanitation procedures. Regarding risk management improvement, the training of health workers by both practical and theoretical methods remains of primary importance. This goal should be achieved by providing specific training courses and by maintaining everyday practices such as correct hand washing, the installation of alarm systems for the constant monitoring of the environment, the creation of areas exclusively reserved for operators and the improvement of the risk perception of workers.

The implementation of these measures coupled with CPS will improve the microenvironmental conditions of workplaces, consequently influencing working performances and the clinical outcomes of patients with positive effects on both the operators and the users.

New laws and regulations are required to solve this problem.

Author Contributions: Conceptualization, M.F. (Margherita Ferrante); methodology, M.F. (Margherita Ferrante); M.F. (Maria Fiore), G.O.C.; software, M.F. (Margherita Ferrante); validation, G.O.C., M.F. (Margherita Ferrante) and M.F. (Maria Fiore); formal analysis, G.L.B., G.C., C.D., G.D., V.M., A.U., G.M. and M.A.C.; investigation, G.O.C., G.L.B., G.C., C.D., A.U. and M.A.C.; data curation, G.O.C., G.L.B., G.C., C.D., G.D., V.M. and G.M.; writing-original draft preparation, M.F. (Margherita Ferrante), G.O.C. and C.D.; writing-review and editing, M.F. (Margherita Ferrante), G.O.C. and M.F. (Maria Fiore); visualization, M.F. (Margherita Ferrante), V.M. and M.F. (Maria Fiore); supervision, M.F. (Margherita Ferrante). All authors have read and agreed to the published version of the manuscript.

Funding: This research received no external funding.

Institutional Review Board Statement: Not applicable.

Informed Consent Statement: Not applicable.

Conflicts of Interest: The authors declare no conflict of interest.

\section{References}

1. Rosso, E.; Lorenzoni, M.; Berti, C. Data analysis of operating room performances for a better management in two Italian Hospitals. In Proceedings of the 5th International Congress on Healthcare \& Hospital Management, Rome, Italy, 3-4 December 2018. [CrossRef]

2. Katz, J.D. Control of the environment in the operating room. Anesth. Analg. 2017, 125, 1214-1218. [CrossRef] [PubMed]

3. Madeo, M. The role of air ventilation and air sampling in reducing the incidence of surgical wound infection rates. Br. J. Theatre Nurs. 1996, 6, 29-32. [PubMed]

4. Chow, T.T.; Yang, X.Y. Ventilation performance in the operating theatre against airborne infection: Numerical study on an ultra-clean system. J. Hosp. Infect. 2005, 59, 138-147. [CrossRef]

5. Chauveaux, D. Preventing surgical-site infections: Measures other than antibiotics. Orthop. Traumatol. Surg. Res. 2015, 101, S77-S83. [CrossRef]

6. Dharan, S.; Pittet, D. Environmental controls in operating theatres. J. Hosp. Infect. 2002, 51, 79-84. [CrossRef] [PubMed]

7. Sartini, M.; Spagnolo, A.M.; Panatto, D.; Perdelli, F.; Cristina, M.L. Improving environmental quality in an operating room: Clinical outcomes and economic implications. J. Prev. Med. Hyg. 2013, 54, 75. [PubMed]

8. Whyte, W.; Lidwell, O.M.; Lowbury, E.J.L.; Blowers, R. Suggested bacteriological standards for air in ultraclean operating rooms. J. Hosp. Infect. 1983, 4, 133-139. [CrossRef]

9. Yezli, S.; Barbut, F.; Otter, J.A. Surface Contamination in Operating Rooms: A Risk for Transmission of Pathogens? Surg. Infect. 2014, 15, 694-699. [CrossRef] 
10. Cosgrove, M.S. Infection control in the operating room. Crit. Care Nurs. Clin. 2015, 27, 79-87. [CrossRef] [PubMed]

11. Varughese, S.; Ahmed, R. Environmental and occupational considerations of anesthesia: A narrative review and update. Anesth. Analg. 2021, 133, 826-835. [CrossRef]

12. Yılmaz, S.; Çalbayram, N.Ç. Exposure to anesthetic gases among operating room personnel and risk of genotoxicity: A systematic review of the human biomonitoring studies. J. Clin. Anesth. 2016, 35, 326-331. [CrossRef]

13. Single Text on Safety at Work (D.LGS.81/08) Updated in November 2020. Available online: https://www.lavoro.gov.it/ documenti-e-norme/studi-e-statistiche/Documents/Testo\%20Unico\%20sulla\%20Salute\%20e\%20Sicurezza\%20sul\%20Lavoro/ Testo-Unico-81-08-Edizione-Giugno\%202016.pdf (accessed on 30 August 2021).

14. Higher Health Council. Ministerial Circular No 5 Professional Exposure to Anesthetics in the Operating Room; Higher Health Council: Rome, Italy, 1989. Available online: http://webcache.googleusercontent.com/search?q=cache:2WmWNTsT_gcJ: www.aosp.bo.it/ files/cm5-89.doc + cd=1\&hl=it\&ct=clnk\&gl=it (accessed on 30 August 2021).

15. Istituto Superiore Prevenzione e Sicurezza del Lavoro (ISPESL). Standards Guidelines Safety and Environmental Hygiene of Departments Traders; Higher Health Council: Rome, Italy, 2009.

16. Higher Health Council. Legislative Decree no. 242 of 19 March 1996 Amendments, and Additions to Legislative Decree no. 626 of 19 September 1994 Implementing Community Directives on the Improvement of the Safety and Health of Workers at Work. (OJ No 104, 06.05.1996 - Suppl. Ordinary No. 75); Higher Health Council: Rome, Italy, 1996. Available online: https:/ /www.gazzettaufficiale. it/eli/id/1996/05/06/096G0217/sg (accessed on 30 August 2021).

17. Higher Health Council. Legislative Decree no. 626 of 19 September 1994 Implementation of Directives 89/391/EEC, 89/654/EEC, 89/655/EEC, 89/656/EEC, 90/269/EEC, 90/270/EEC, 90/394/EEC and 90/679/EEC on the Improvement of the Safety and Health of Workers at Work. (OJ Serie Generale n.265 of 12.11.1994-Suppl. Ordinary n. 141); Higher Health Council: Rome, Italy, 1994. Available online: https://www.bosettiegatti.eu/info/norme/statali/1994_0626.htm (accessed on 30 August 2021).

18. Higher Health Council. Decree of the President of the Republic 14 January 1997 Minimum Technological and Organizational Requirements for the Exercise of Health Activities by Public and Private Facilities. (OJ Serie Generale n.42 del 20-02-1997-Suppl. Ordinario n. 37); Higher Health Council: Rome, Italy, 1997.

19. Masia, M.D.; Dettori, M.; Liperi, G.; Deriu, G.M.; Posadino, S.; Maida, G.; Mura, I. Thermal comfort in perioperatory risk's evaluation. Ann. Ig. Med. Prev. Comunita 2009, 21, 251-258.

20. Pasquarella, C.; Balocco, C.; Colucci, M.E.; Saccani, E.; Paroni, S.; Albertini, L.; Vitali, P.; Albertini, R. The influence of surgical staff behavior on air quality in a conventionally ventilated operating theatre during a simulated arthroplasty: A case study at the University Hospital of Parma. Int. J. Environ. Res. Public Health 2020, 17, 452. [CrossRef]

21. Möhlenkamp, M.; Schmidt, M.; Wesseling, M.; Wick, A.; Gores, I.; Müller, D. Thermal comfort in environments with different vertical air temperature gradients. Indoor Air 2019, 29, 101-111. [CrossRef]

22. UNI EN ISO. Ergonomics of Environments Thermal-Analytical Determination and Interpretation of Thermal Well-Being by Calculation Pmv and Ppd Indices and Local Thermal Welfare Criteria; UNI EN ISO: 2006. Available online: https:/ / www.iso. org/standard/39155.html (accessed on 30 August 2021).

23. Weber, C.F.; Werth, J.T. Culturing life from air: Using a surface air system to introduce discovery-based research in aerobiology into the undergraduate biology curriculum. J. Microbiol. Biol. Educ. 2015, 16, 72-74. [CrossRef] [PubMed]

24. UNI EN 550:1996-Sterilization of Medical Devices-Method for the Validation and Systematic Control of Ethylene Oxide Sterilization. Available online: http:/ / store.uni.com/catalogo/uni-en-550-1996 (accessed on 30 August 2021).

25. UNI EN 552:2002—Sterilization of Medical Devices-Method for the Validation and Systematic Control of Sterilization with Ionizing Radiation. Available online: http:/ / store.uni.com/catalogo/uni-en-552-2002?josso_back_to=http:/ /store.uni.com/ josso-security-check.php\&josso_cmd=login_optional\&josso_partnerapp_host=store.uni.com (accessed on 30 August 2021).

26. UNI EN 554:1996-Sterilization of Medical Devices. Method for Validation and Systematic Control of Steam Sterilization. Sterilization of Medical Devices. Method for Validation and Systematic Control of Steam Sterilization. Available online: http:/ / store.uni.com/catalogo/uni-en-554-1996 (accessed on 30 August 2021).

27. UNI EN 556:2000—Sterilization of Medical Devices—Requirements for Terminally Sterilized Medical Devices Bearing the Indication "STERILE". Available online: http:/ / store.uni.com/catalogo/uni-en-556-2000 (accessed on 30 August 2021).

28. National Institute for Occupational Safety and Health (NIOSH). Criteria for a Recommended Standard Occupational Exposure to Waste Anesthetic Gases and Vapors; National Institute for Occupational Safety and Health: Washington, DC, USA, 1977.

29. Ritzu, S.; Boccalon, P.; Sanchez, M.A.; Arcangeli, G.; Capelli, V. Anesthetic gases exposure: Findings from a 13 year environmental and biological monitoring in a hospital company. G. Ital. Med. Lav. Ergon. 2007, 29 (Suppl. S3), 411-413.

30. Howorth, F.H. Air flow patterns in the operating theatre. Eng. Med. 1980, 9, 87-92. [CrossRef] [PubMed]

31. Tang, C.-S.; Wan, G.-W. Air quality monitoring of the post-operative recovery room and locations surrounding operating theaters in a medical center in Taiwan. PLoS ONE 2013, 8, e61093. [CrossRef] [PubMed]

32. La Fauci, V.; Genovese, C.; Facciolà, A.; Palamara, M.A.R.; Squeri, R. Five-year microbiological monitoring of wards and operating theatres in southern Italy. J. Prev. Med. Hyg. 2017, 58, E166.

33. Jafari, A.; Bargeshadi, R.; Jafari, F.; Mohebbi, I.; Hajaghazadeh, M. Environmental and biological measurements of isoflurane and sevoflurane in operating room personnel. Int. Arch. Occup. Environ. Health 2018, 91, 349-359. [CrossRef]

34. Vangipuram, S.L.T.; Mohanty, S.P.; Kougianos, E. CoviChain: A blockchain based framework for non repudiable contact tracing in healthcare cyber-physical systems during pandemic outbreaks. SN Comput. Sci. 2021, 2, 346. [CrossRef] [PubMed] 